\title{
Rumination time around calving: An early signal to detect cows at greater risk of disease
}

\author{
L. Calamari, ${ }^{* 1}$ N. Soriani, ${ }^{*}$ G. Panella,† F. Petrera, $\ddagger$ A. Minuti, ${ }^{*}$ and E. Trevisi ${ }^{*}$ \\ *Istituto di Zootecnica, Università Cattolica del Sacro Cuore, Via Emilia Parmense, 84, 29122 Piacenza, Italy \\ †Azienda Sperimentale "Vittorio Tadini," 29027 Gariga di Podenzano, Piacenza, Italy \\ $\ddagger$ Consiglio per la Ricerca e la sperimentazione in Agricoltura (Centro di Ricerca per le Produzioni Foraggere e Lattiero-Casearie), \\ sede di Cremona, via Porcellasco 7, 26100 Cremona, Italy
}

\section{ABSTRACT}

The main objective of this experiment was to evaluate the use of rumination time (RT) during the peripartum period as a tool for early disease detection. The study was carried out in an experimental freestall barn and involved 23 Italian Friesian cows (9 primiparous and 14 multiparous). The RT was continuously recorded by using an automatic system (Hr-Tag, SCR Engineers Ltd., Netanya, Israel), and data were summarized in 2-h intervals. Blood samples were collected from $30 \mathrm{~d}$ before calving to $42 \mathrm{~d}$ in milk (DIM) to assess biochemical indicators related to energy, protein, and mineral metabolism, as well as markers of inflammation and some enzyme activities. The liver functionality index, which includes some negative acute-phase proteins and related parameters (albumin, cholesterol, and bilirubin), was used to evaluate the severity of inflammatory conditions occurring around calving. The cows were retrospectively categorized according to RT observed between 3 and 6 DIM into those with the lowest (L) and highest (H) RT. The average RT before calving ( -20 to $-2 \mathrm{~d}$ ) was $479 \mathrm{~min} / \mathrm{d}$ (range 264 to 599 ), reached a minimum value at calving (30\% of RT before calving), and was nearly stable after 15 DIM (on average $452 \mathrm{~min} / \mathrm{d}$ ). Milk yield in early lactation (on average $26.8 \mathrm{~kg} / \mathrm{d}$ ) was positively correlated with RT $(\mathrm{r}=0.33)$. After calving, compared with $\mathrm{H}$ cows, the $\mathrm{L}$ cows had higher values of haptoglobin (0.61 and 0.34 $\mathrm{g} / \mathrm{L}$ at 10 DIM in L and $\mathrm{H}$, respectively) for a longer time, had a greater increase in total bilirubin (9.5 and $5.7 \mu \mathrm{mol} / \mathrm{L}$ at $5 \mathrm{DIM}$ in $\mathrm{L}$ and $\mathrm{H}$ ), had greater reductions of albumin (31.2 and $33.5 \mathrm{~g} / \mathrm{L}$ at 10 DIM in L and $\mathrm{H}$ ) and paraoxonase (54 and $76 \mathrm{U} / \mathrm{mL}$ at $10 \mathrm{DIM}$ in $\mathrm{L}$ and $\mathrm{H}$ ), and had a slower increase of total cholesterol (2.7 and $3.2 \mathrm{mmol} / \mathrm{L}$ at $20 \mathrm{DIM}$ in L and H). Furthermore, a lower average value of liver functionality index was observed in L (-6.97) compared with $\mathrm{H}(-1.91)$

Received November 12, 2013.

Accepted February 26, 2014.

${ }^{1}$ Corresponding author: luigi.calamari@unicatt.it cows. These results suggest that severe inflammation around parturition is associated with a slower increase of RT after calving. Furthermore, more than $90 \%$ of the cows in the L group had clinical diseases in early lactation compared with $42 \%$ of the $\mathrm{H}$ cows. Overall, our results demonstrate the utility of monitoring RT around calving, and in particular during the first week of lactation, as a way to identify in a timely fashion those cows at a greater risk of developing a disease in early lactation.

Key words: rumination time, dairy cow, metabolic disease, transition period

\section{INTRODUCTION}

Rumination is a cyclical process characterized by regurgitation, remastication, and reswallowing (Beauchemin, 1991). This process is variable and influenced by many factors including acute stress (Herskin et al., 2004), disease (Welch, 1982; Hansen et al., 2003), diet composition and forage quality (Welch and Smith, 1970), and management errors (Grant and Albright, 2006). Variability in rumination is caused by ethological behavior, reproduction status, production level, climatic condition, and health status. The recent introduction of indirect methods to measure rumination time, based on analysis of vocal signs (Hr-Tag rumination monitoring system, SCR Engineers Ltd., Netanya, Israel), allows automatic measurement of rumination time and analysis of daily pattern in rumination time (RT).

Our recent study (Soriani et al., 2012) using this new system during the peripartum period uncovered differences in RT between healthy and sick cows. In particular, a lower RT during the first 10 DIM was observed in cows with health disorders compared with healthy cows (Soriani et al., 2012). Furthermore, cows with lower RT in early lactation were characterized by a greater increase of plasma positive acute-phase proteins after calving, as well as a slower increase of negative acute-phase proteins, indicative of a marked inflammatory status around calving. These alterations were highlighted by indices based on several negative 
acute-phase proteins proposed by Bertoni et al. (2008), Trevisi et al. (2012a), and Bertoni and Trevisi (2013).

Timely therapies are required to improve welfare and performance during the transition period, when the incidence of diseases is highest (Lewis, 1997; Trevisi et al., 2011, 2012a). Together, the results available to date seem to support the use of RT measurement around calving as a tool for early detection of sick cows or cows with a higher probability of developing health disorders around calving. Therefore, the objective of this study was to examine the possibility of early detection of health problems in dairy cows during the peripartum period by recording their RT and daily rumination behaviors. In addition, the RT data were used to assess relationships to the incidence of clinical symptoms of diseases and metabolic-inflammatory indices in the blood.

\section{MATERIALS AND METHODS}

\section{Animal and Management}

The research protocol and animal care were in accordance with Directive 2010/63/EU of the European Parliament and of the Council of September 22, 2010, on the protection of animals used for scientific purposes.

The study involved 23 Italian Friesian dairy cows (14 primiparous: PR; and 9 multiparous: $\mathbf{M P}$ ) from the last month of pregnancy through wk 6 of lactation. All cows calved within a period of 2 mo (from July 4 to September 6, 2011); most cows (18) calved between July 20 and August 20. Each cow in the study was examined daily and records of all health-related problems as well as trauma and pharmacological treatments that occurred throughout the study were recorded.

The animals involved in this study were housed in a freestall barn at the experimental farm "Vittorio Tadini," located near Piacenza, Italy $\left(45^{\circ} 01^{\prime} \mathrm{N}, 9^{\circ} 40^{\prime} \mathrm{E} ; 68\right.$ $\mathrm{m}$ above sea level). Dry cows and early lactating cows were kept in 2 separate pens. Dry cows were housed in a pen with straw-bedded pack as resting area; the individual area available for each animal was $8 \mathrm{~m}^{2}$. The cows were moved from a far-off dry-period pen to a late-pregnancy pen 1 mo before expected calving day, and the heifers were moved 2 mo before their expected calving day. Cows were allowed to calve in the pen holding late-pregnant cows. After calving, the cows were housed in the pen (cubicles as resting area) for early lactating cows until $40 \mathrm{~d}$ postpartum. Fresh water was available ad libitum within each pen. Each pen was equipped with axial-flow fans installed along the feed driveway. Sprinklers were placed perpendicular to the air flow of the fans along the feed alley. Fans and sprinklers were thermostatically controlled: fans were switched on at $23^{\circ} \mathrm{C}$ and sprinklers at $27^{\circ} \mathrm{C}$. Constant managerial conditions (operators, similar batches of feed, milking frequency, and working routine) were maintained during the experimental period.

Cows were milked twice daily (0330 and $1500 \mathrm{~h}$ ), and milk yield (MY) at each milking was recorded electronically (Alpro, DeLaval, Tumba, Sweden). An automatic weighing system (Alpro, DeLaval) was installed at the exit of the milking parlor to measure BW. Cows of each pen were fed a specific TMR ad libitum once daily at $0730 \mathrm{~h}$. To ensure that cows had ad libitum access to the TMR, the amount offered was assessed daily with the aim of producing 3 to $8 \%$ refusals.

\section{Measurements and Analyses}

Microclimatic Conditions. Temperature and relative humidity of the inside barn were recorded daily during the study period using 2 electronic probes (Gemini Data Logger, Chichester, UK) connected to a data logger programmed to record every $30 \mathrm{~min}$. Mean daily temperature and humidity and daily minimum and maximum temperatures and humidity were calculated from temperature and relative humidity data recorded throughout the study. Data were used to compute a composite climatic welfare index - temperaturehumidity index (THI) - according to the formula of Kelly and Bond (1971), as reported by Ingraham et al. (1979). Mean daily THI, daily minimum THI, and daily maximum THI were also calculated throughout the study. Furthermore, the average of the mean daily THI observed during the first week of lactation was calculated for each cow.

Feed and Diets. Representative samples of forages, concentrate mixtures, and TMR were collected twice monthly. All samples were pooled monthly for analyses. Chemical composition (moisture, fat, $\mathrm{CP}$, crude fiber, NDF, ADF, ADL, starch, and ash) was determined using standard procedures, and nutritive values were calculated according to NRC (2001). The chemical and nutritive characteristics of the diet of dry and lactating cows were calculated monthly. Furthermore, the particle size distribution of the TMR was determined with the New Penn State Forage Particle Separator (PSPS) system (Kononoff et al., 2003).

Rumination Time. Rumination time was measured using the Hr-Tag rumination monitoring system (SCR Engineers Ltd.). The system consisted of rumination loggers, stationary readers, and software for processing the electronic data (Data Flow software, SCR Engineers Ltd.). A neck collar positioned the logger on the left side of the neck. The logger contained a microphone 
to record the distinctive sounds of regurgitation and rumination. Data were calculated and summarized at 2-h intervals and stored in the memory of the logger.

The data of RT obtained with the automatic system were summarized at 2-h intervals and used to calculate the following variables: (1) total daily RT, by summing each 2-h interval values recorded between 0800 to 0800 $\mathrm{h}$ of the following day; and (2) daytime RT, by summing the 2 -h intervals values recorded between 0800 and $2000 \mathrm{~h}$, and nighttime RT between 2000 and 0800 $\mathrm{h}$ of the following day. These values were also expressed as percentage of daily RT.

Blood. Blood samples from the jugular vein were collected in 10-mL lithium heparin tubes (18 IU of lithium heparin/mL, Vacuette, Kremsmünster, Austria) before feed distribution at $-14,-7,5,10,20$, and $30 \mathrm{~d}( \pm 1 \mathrm{~d})$ from calving. Samples were immediately placed in an ice-water bath after collection.

A small amount of blood was used for hematocrit (packed cell volume) determination in a capillary tube after high-speed centrifugation $(15,000 \times g$ for $10 \mathrm{~min}$ at room temperature). The remaining blood was centrifuged $\left(3,500 \times g\right.$ for 16 min at $\left.4^{\circ} \mathrm{C}\right)$ and the plasma was separated into several aliquots for storage at $-20^{\circ} \mathrm{C}$ until further analysis. Plasma metabolites were analyzed at $37^{\circ} \mathrm{C}$ by automated clinical analyzer (ILAB 600, Instrumentation Laboratory, Lexington, MA). Commercial kits were used to measure glucose, total cholesterol, urea, calcium, inorganic phosphorus, magnesium, total protein, albumin, total bilirubin, and creatinine (Instrumentation Laboratory), NEFA, zinc (Wako Chemicals GmbH, Neuss, Germany), and BHBA (BHBA kit, Randox, Antrim, UK). Kinetic analysis was used to determine activity of alkaline phosphatase (EC 3.1.3.1), aspartate aminotransferase (EC 2.6.1.1), and $\gamma$-glutamyltransferase (EC 2.3.2.2) using commercial kits (Instrumentation Laboratory). Ceruloplasmin and haptoglobin were determined with reagents prepared according to the methods reported by Bertoni et al. (2008). Furthermore, plasma paraoxonase activity was measured as previously reported by Bionaz et al. (2007). A test for blood ketone bodies (Optium Xceed, Abbott, IL) was used during the first week of lactation and ketosis diagnosed when the level was $>1 \mathrm{mmol} / \mathrm{L}$.

Albumin, cholesterol, and bilirubin data collected in the periparturient period were used to determine the liver functionality index (LFI) according to Trevisi et al. (2011). This index takes into account changes in albumin, lipoproteins (measured as total cholesterol) and total bilirubin (its secretory enzyme is synthesized by the liver) occurring between 3 and 28 DIM. The LFI calculation is carried out in 2 steps (see Trevisi et al., 2011 for a thorough explanation); the first one considers the values of the 3 parameters observed on $d$
3 and their changes between $\mathrm{d} 3$ and 28. In the second step, these partial indices were standardized according to average values observed in "healthy" cows (in optimal conditions at clinical examination) calculated as described in the first step. Thus, low LFI values are associated with a large inflammatory response and vice versa.

\section{Data Processing and Statistical Analysis}

The cows were retrospectively categorized according to the level of RT observed between 3 and 6 DIM. This classification was obtained by sorting cows blocked by parity according to RT level observed between 3 and 6 DIM, and the cows with the lowest RT values $50 \%$ of the cows) were assigned to the low-RT group (L; $7 \mathrm{MP}$ and $4 \mathrm{PR}$ ), whereas the remaining $50 \%$ of cows, with the highest RT values, were assigned to the high-RT group (H; $7 \mathrm{MP}$ and $5 \mathrm{PR}$ ).

All statistical analyses were performed using the SAS software package (version 9.2; SAS Inst. Inc., Cary, NC). Data were tested for non-normality by the Shapiro-Wilk test (SAS Inst. Inc.). In case of non-normality, parameters were normalized by log or exponential transformation. Transformations were performed for total bilirubin, haptoglobin, aspartate aminotransferase, $\gamma$-glutamyltransferase, NEFA, and BHBA. The RT variables, MY, and plasma indices were analyzed with repeated-measures ANOVA using a mixed model (MIXED procedure; SAS Inst. Inc.). The model included the fixed effect of parity (PR and $\mathrm{MP}$ ), rumination time ( $\mathrm{H}$ and $\mathrm{L}$ cows), time from calving, interaction between group $\times$ time from calving, and individual variability (within cow $\times$ group). The analysis was carried out using 3 covariance structures: autoregressive order, compound symmetry, and spatial power. These were ranked according to their Akaike and Schwarz Bayesian information criteria, with the one having the least information criterion being eventually chosen (Littell et al., 1998). For each treatment, least squares means were computed, and preplanned pairwise comparisons (PDIFF option, SAS Inst. Inc.) were conducted when the F-test of one of the main factors (time to calving, group, parity, and interactions) was significant at $P<0.10$. Statistical significance was designated as $P<0.05$ and tendencies were declared at $P<0.10$. Pearson and partial correlations between RT variables (using average values of the previous 3 d) and MY as well as plasma indices were calculated using the CORR and MANOVA procedure (SAS Inst. Inc.). These correlations were calculated using all observations and were also calculated separately for the pre- and postcalving period. Partial correlations were adjusted for DIM and MY. 


\section{RESULTS}

Our population was composed of $39 \% \mathrm{PR}$ and $61 \%$ $\mathrm{MP}$ cows. The mean \pm SD BW at the end of the first month of lactation was $595.0 \pm 35.5 \mathrm{~kg}$ for $\mathrm{PR}$ and $685.0 \pm 35.2 \mathrm{~kg}$ for MP. On average, MY during the first month of lactation was $24.7 \pm 4.9$ and $28.9 \pm 8.3$ $\mathrm{kg} / \mathrm{d}$ for PR and MP, respectively.

During the trial, mean daily THI was $72.73 \pm 2.92$, and the cows experienced daily maximum THI $>72$ on every day during the trial. During the trial, the daily minimum THI averaged $65.18 \pm 3.47$. The mean daily THI observed during the first week of lactation was $73.21 \pm 3.11$ and $72.70 \pm 3.20$ in $\mathrm{H}$ and $\mathrm{L}$ cows, respectively. The cows without clinical diseases after calving had a mean daily THI during the first week of lactation of $73.10 \pm 3.31$. This value was very close to that observed in cows diagnosed with at least one clinical disease after calving $(72.52 \pm 3.13)$.

The composition, chemical analysis, and nutritive value of diets fed to cows during the dry period and early lactation are reported in Table 1 , as well as the particle size distribution of the TMR fed to early lactating cows. Despite high forage NDF content $(27.5 \%$ of DM), the TMR of early lactating cows was characterized by a small amount of material retained on the 19.0- and 8.0-mm screens and a relatively high proportion of material retained on the bottom pan.

The mean value of daily RT before calving (from -20 to $-2 \mathrm{~d}$ ) averaged $479 \mathrm{~min} / \mathrm{d}$, and this value ranged from 264 to $599 \mathrm{~min} / \mathrm{d}$ among cows. No significant difference was observed for RT between PR and MP cows. A reduction of daily RT of $70 \%$ (on average) of the value observed during the dry period was observed on the day of calving.

In cows with higher RT between 3 and 6 DIM (H group), the increase of RT after calving was very rapid; for example, at 3 DIM, RT had already reached the average value observed in the whole first month of lactation (Figure 1). The increase in RT after the day of calving was slower in L cows compared with $\mathrm{H}$ cows. Indeed, L cows reached a stable level of RT only after 15 DIM (Figure 1). From 15 to 40 DIM, the average RT calculated, including all cows, was 452 $\min /$ d. Interestingly, almost all cows (91\%) in the L group were diagnosed with at least one clinical disease after calving (retained placenta and endometritis in 1 cow; ketosis in 3 cows; lameness in 5 cows, with clinical manifestation at 7 DIM in 1 of them and between 9 and 12 DIM in the other 4 cows; and mastitis in 1 cow at 7 DIM). Conversely, only $42 \%$ (5 cows) in the $\mathrm{H}$ group showed clinical diseases during the first month of lactation. In this group, the clinical diseases observed were mastitis (3 cows with clinical signs at
Table 1. Composition, chemical analysis, and nutritive value of diets fed to cows during dry period and in early lactation (\% of DM)

\begin{tabular}{|c|c|c|}
\hline Item & $\begin{array}{l}\text { Dry } \\
\text { period }\end{array}$ & Lactation \\
\hline \multicolumn{3}{|l|}{ Ingredient } \\
\hline Corn silage & 25.63 & 17.20 \\
\hline Triticale silage & & 4.27 \\
\hline Grass hay & 52.03 & 10.30 \\
\hline Alfalfa hay & & 21.76 \\
\hline Wheat straw & 15.45 & \\
\hline Corn meal & & 25.70 \\
\hline Soybean meal & 6.04 & 4.24 \\
\hline Commercial concentrate $^{1}$ & & 14.16 \\
\hline Dry sugar beet pulp & & 1.47 \\
\hline Sodium bicarbonate & & 0.90 \\
\hline Mineral and vitamin supplement ${ }^{2}$ & 0.85 & \\
\hline \multicolumn{3}{|l|}{ Nutrient } \\
\hline $\mathrm{NE}_{\mathrm{L}},{ }^{3} \mathrm{Mcal} / \mathrm{kg}$ of $\mathrm{DM}$ & 1.35 & 1.55 \\
\hline $\mathrm{CP}$ & 11.49 & 16.10 \\
\hline Ether extract & 2.72 & 3.22 \\
\hline Starch & 8.41 & 26.74 \\
\hline Forage & 94.02 & 54.28 \\
\hline NDF & 52.00 & 34.58 \\
\hline Forage NDF & 51.16 & 27.54 \\
\hline \multicolumn{3}{|l|}{ PSPS, ${ }^{4} \%$ of TMR retained on sieves } \\
\hline Upper sieve, particles >19 mm & & 8.0 \\
\hline Middle sieve, particles $>8 \mathrm{~mm}$ & & 36.1 \\
\hline Bottom sieve, particles $>1.18 \mathrm{~mm}$ & & 35.3 \\
\hline Bottom pan, particles $<1.18 \mathrm{~mm}$ & & 20.6 \\
\hline
\end{tabular}

Contained, per kilogram, $27 \mathrm{~g}$ of $\mathrm{NaHCO}_{3} ; 26.8 \mathrm{~g}$ of $\mathrm{CaCO}_{3} ; 6.7 \mathrm{~g}$ of $\mathrm{NaCl} ; 6.7 \mathrm{~g}$ of $\mathrm{Ca}\left(\mathrm{H}_{2} \mathrm{PO}_{4}\right) ; 10 \mathrm{~g}$ of $\mathrm{MgO} ; 1 \mathrm{~g}$ of $\mathrm{ZnSO}_{4} \cdot 7 \mathrm{H}_{2} \mathrm{O} ; 13.9 \mathrm{mg}$ of $\mathrm{Cu} ; 37.0 \mathrm{mg}$ of $\mathrm{Mn} ; 139 \mathrm{mg}$ of $\mathrm{Zn} ; 0.19 \mathrm{mg}$ of Co; $3.2 \mathrm{mg}$ of I; 0.37 $\mathrm{mg}$ of Se; 28,000 IU of vitamin A; 2,800 IU of vitamin D; and $139 \mathrm{mg}$ of vitamin E.

${ }^{2}$ Contained, per kilogram, $125 \mathrm{mg}$ of $\beta$-carotene; $1,200,000 \mathrm{IU}$ of vitamin $\mathrm{A} ; 200,000 \mathrm{IU}$ of vitamin $\mathrm{D}_{3} ; 2,500 \mathrm{mg}$ of vitamin $\mathrm{E}$ acetate ( $\alpha$-tocopherol 91\%); $100 \mathrm{mg}$ of vitamin $\mathrm{B}_{1} ; 150 \mathrm{mg}$ of vitamin $\mathrm{B}_{2} ; 100$ $\mathrm{mg}$ of vitamin $\mathrm{B}_{6} ; 2 \mathrm{mg}$ of vitamin $\mathrm{B}_{12} ; 15,000 \mathrm{mg}$ of vitamin PP; 200 $\mathrm{mg}$ of vitamin $\mathrm{K}_{3} ; 10,000 \mathrm{mg}$ of choline chloride; $100 \mathrm{mg}$ of D-pantothenic acid; $50 \mathrm{mg}$ of folic acid; $10 \mathrm{mg}$ of $\mathrm{Co}\left[\mathrm{Co}\left(\mathrm{NO}_{3}\right)_{2} \cdot 6 \mathrm{H}_{2} \mathrm{O}\right] ; 2,500 \mathrm{mg}$ of $\mathrm{Fe}\left(\mathrm{FeSO}_{4} \cdot \mathrm{H}_{2} \mathrm{O}\right) ; 100 \mathrm{mg}$ of I (KI); $1,500 \mathrm{mg}$ of $\mathrm{Mn}\left(\mathrm{MnSO}_{4} \cdot \mathrm{H}_{2} \mathrm{O}\right)$; $250 \mathrm{mg}$ of $\mathrm{Cu}\left(\mathrm{CuSO}_{4} \cdot 5 \mathrm{H}_{2} \mathrm{O}\right) ; 5,000 \mathrm{mg}$ of $\mathrm{Zn}\left(\mathrm{ZnSO}_{4} \cdot \mathrm{H}_{2} \mathrm{O}\right) ; 15 \mathrm{mg}$ of $\mathrm{Se}\left(\mathrm{Na}_{2} \mathrm{SeO}_{3}\right)$; and $15 \mathrm{mg}$ of selenomethionine.

${ }^{3}$ According to NRC (2001) and calculated using Razio-Best software of the Istituto di Zootecnica, Università Cattolica del Sacro Cuore (Piacenza, Italy).

${ }^{4}$ PSPS $=$ particle size distributions measured using the new Penn State Particle Separator (Kononoff and Heinrichs, 2003a).

3,7 , and 10 DIM) and lameness (2 cows with clinical manifestation at 3 DIM and 25 DIM). Moreover, MY during the first month of lactation was greater $(P<$ $0.001)$ in $\mathrm{H}(30.3 \mathrm{~kg} / \mathrm{d})$ compared with $\mathrm{L}(22.5 \mathrm{~kg} / \mathrm{d})$ cows. A significant partial correlation was observed between MY and the average daily RT of the previous $3 \mathrm{~d}(\mathrm{r}=0.33 ; P<0.001)$.

In all cows, RT was greater at nighttime than daytime before calving (nighttime RT $=64.8 \%$ of daily RT) and after calving (nighttime RT $=64.4 \%$ of daily RT). The behavior of daily RT observed in wk 1 of lactation (average values from 3 to 8 DIM) is shown in Figure 2. In each 2-h interval, the RT was greater in $\mathrm{H}$ compared 


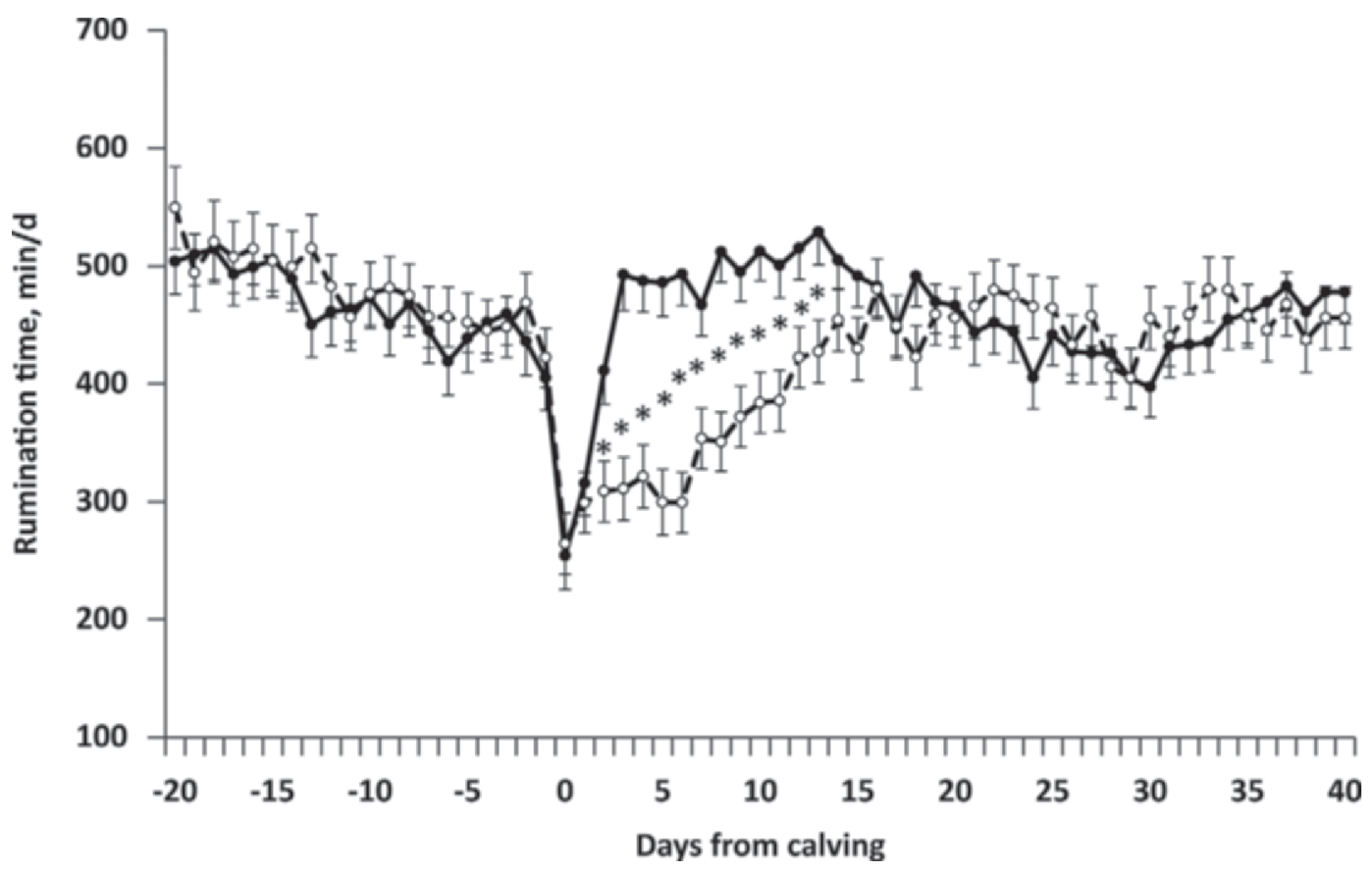

Figure 1. Daily pattern of rumination time (LSM \pm SEM) during the transition period in cows categorized according to rumination time (RT) observed between 3 and 6 DIM (higher RT, $\bullet$; lower RT, $\bigcirc$ ). Asterisk $\left(^{*}\right)$ indicates a difference between higher and lower RT cows, $P<$ 0.05 .

with L (Figure 2a). The RT values observed in each 2-h interval expressed as a percentage of daily RT (Figure $2 \mathrm{~b}$ ) were greater in $\mathrm{H}$ during nighttime (significant difference in the 2-h interval before midnight) and greater in $\mathrm{L}$ during and after feed distribution (significant difference in the 2-h interval of TMR distribution in the morning) and at milking time (not significant).

Almost all plasma variables measured in this study were affected by time relative to calving. Cows in the $\mathrm{H}$ group had a pattern of change similar to those of healthy cows (Bionaz et al., 2007; Bertoni et al., 2008; Trevisi et al., 2012a) for all parameters. Conversely, some plasma parameters in L cows had deviations from the typical profiles observed in the peripartum period. For instance, significant differences were mainly observed between 5 and 10 DIM among the groups for some positive (e.g., haptoglobin) and negative acutephase proteins (albumin) or related parameters (cholesterol, paraoxonase, bilirubin), as well as NEFA, BHBA, calcium, and aspartate aminotransferase (Table 2).

Among the positive acute-phase proteins, haptoglobin had a greater increase around calving in L than in $\mathrm{H}$ cows. Thereafter, the values remained higher in $\mathrm{L}$ compared with $\mathrm{H}$, and the differences among groups reached significance $(P<0.05)$ at 10 DIM (Figure 3). Among the negative acute-phase proteins, plasma albumin strongly decreased after calving in L cows, and differences between $\mathrm{L}$ and $\mathrm{H}$ cows became significant at 10 DIM (Figure 4a). Moreover, total cholesterol, used as index of plasma lipoproteins, increased slowly in $\mathrm{L}$ compared with $\mathrm{H}$ cows, and differences between $\mathrm{L}$ and $\mathrm{H}$ became significant at 20 DIM (Figure 4b). A marked increase of total bilirubin at 5 DIM was observed in L; their values differed $(P<0.05)$ at 5 and 10 DIM from those of $\mathrm{H}$ cows (Figure 4c). A negative partial correlation between total bilirubin and RT in lactating cows ( $\mathrm{r}$ $=-0.35 ; P<0.01)$ was observed. A strong reduction of plasma paraoxonase was observed at 10 DIM in L cows and was significantly lower than that in $\mathrm{H}$ cows at 10 DIM $(P<0.01)$; thereafter, the values in L cows remained numerically lower than those of $\mathrm{H}$ cows (Figure 4d). A positive correlation between paraoxonase and RT (calculated as average value between 3 and 6 DIM) was also observed at 10 DIM (Table 3 ).

Plasma glucose after calving was greater in $\mathrm{L}$ cows compared with $\mathrm{H}$ cows, with significant differences at 20 DIM (Figure 5a). Greater NEFA concentrations were observed after calving in $\mathrm{L}$ compared with $\mathrm{H}$ cows, and significant differences $(P<0.05)$ were observed at 10 DIM (Figure 5b). A weak negative partial correlation between NEFA and RT $(\mathrm{r}=-0.23 ; P=0.04)$ was observed during lactation. Greater values in L compared with $\mathrm{H}$ cows were also observed after calving for plasma BHBA, and significant differences were observed at 10 

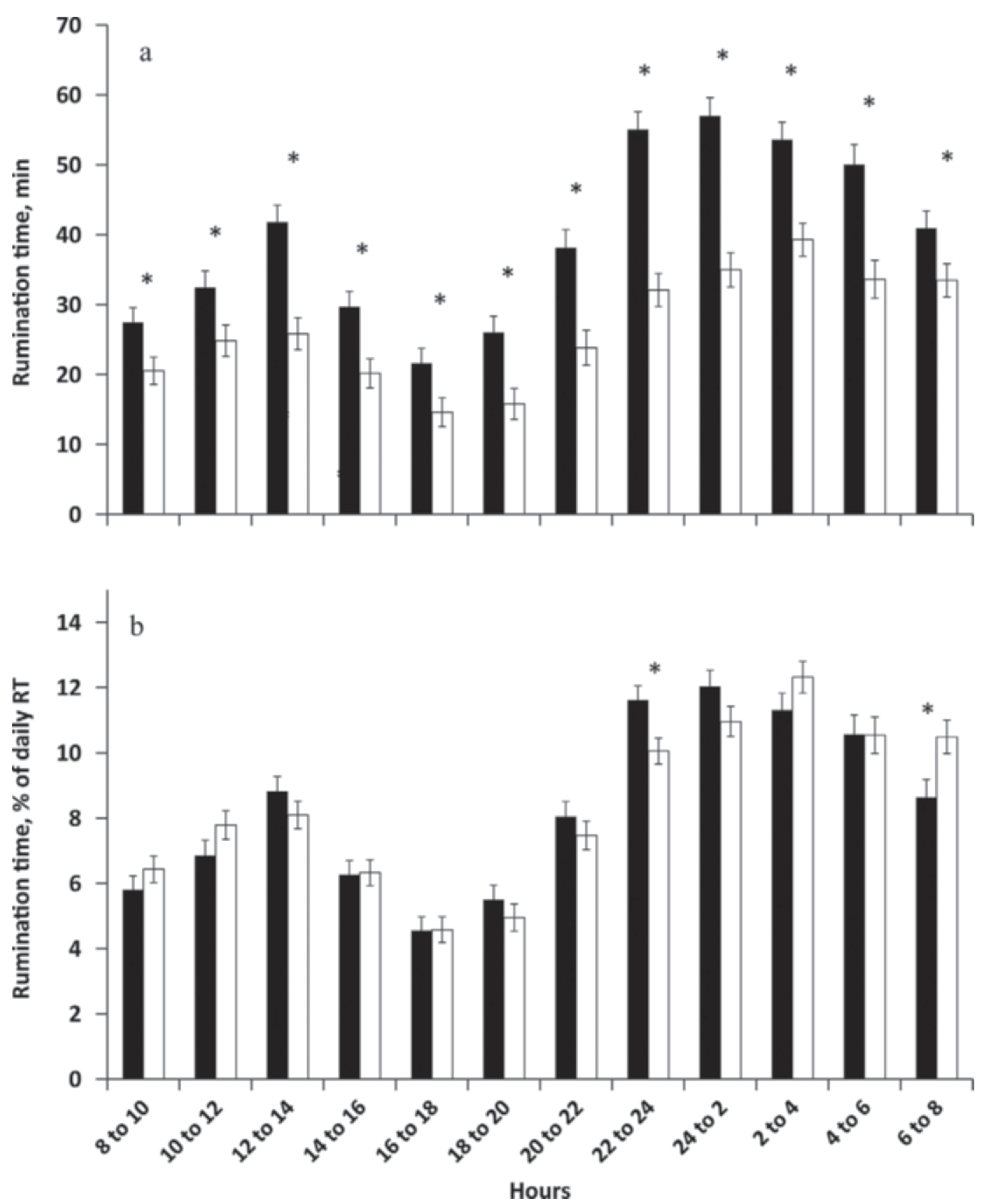

Figure 2. Daily pattern of rumination time (LSM \pm SEM) in early lactation (average values from 3 till 8 DIM) in cows categorized according to rumination time (RT) observed between 3 and 6 DIM (higher RT, black bars, $\mathrm{n}=12$; lower RT, white bars, $\mathrm{n}=11$ ). The TMR was delivered at $0730 \mathrm{~h}$ and cows were milked at 0330 and $1500 \mathrm{~h}$. Asterisk $\left(^{*}\right)$ indicates a difference between higher and lower RT cows, $P<0.05$.

DIM $(P<0.01 ;$ Figure 5c). Furthermore, a weak negative partial correlation was observed between BHBA and RT during lactation $(\mathrm{r}=-0.25 ; P=0.03)$.

The LFI was low in all cows studied and the value was often negative. Nevertheless, $\mathrm{L}$ cows had a lower $(P$ $<0.01)$ average value of LFI $(-6.97 \pm 3.91)$ compared with $\mathrm{H}$ cows $(-1.91 \pm 1.59)$. The LFI was positively correlated with average RT between 3 and 6 DIM (r =
$0.75 ; P<0.001 ;$ Figure 6$)$. The LFI was also highly and positively correlated $(P<0.001)$ with each daily RT from 2 to 9 DIM ( $\mathrm{r}=0.85,0.77$, and 0.66 at DIM 3,6 , and 9 , respectively); then, the correlation decreased but remained significant $(P<0.05)$ until 13 DIM $(r=0.45$ to 0.58 ). No correlation was observed between LFI and average values of daily THI recorded during the first week of lactation in each cow. 


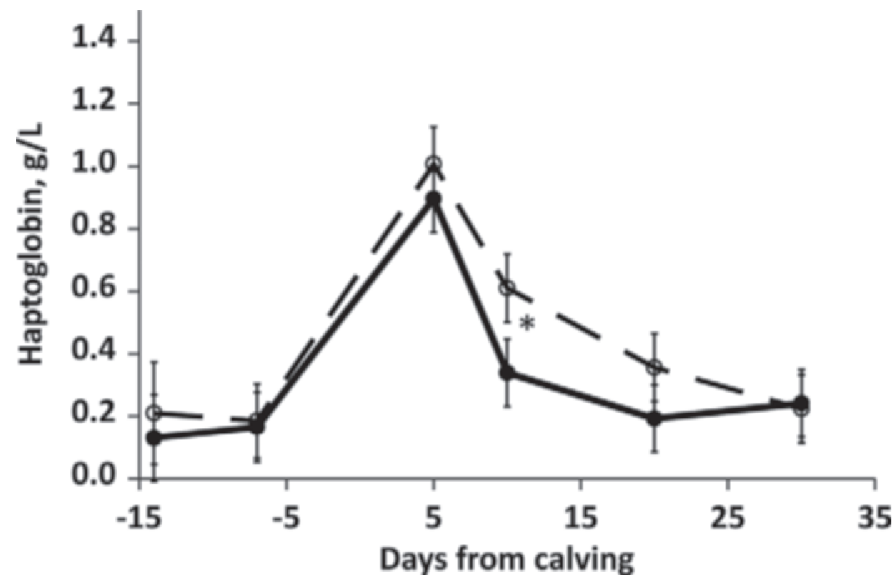

Figure 3. Pattern of plasma haptoglobin in cows categorized according to rumination time (RT) observed between 3 and 6 DIM (higher RT, $\bullet, \mathrm{n}=12$; lower RT, $\mathrm{O}, \mathrm{n}=11$ ). Values are $\mathrm{LSM} \pm \mathrm{SEM}$; asterisk $(*)$ indicates a difference between higher and lower RT cows, $P<0.05$

\section{DISCUSSION}

\section{Rumination Time}

Indirect methods of monitoring rumination have been proposed recently. In our study, we adopted the system (Hr-Tag rumination monitoring system, SCR Engineers Ltd.) previously described and validated by Schirmann et al. (2009). The system accurately measures RT daily rumination behavior in dairy cows in research and commercial settings (Schirmann et al., 2009). Several recent studies support the utility of this system in research settings (Adin et al., 2009; Schirmann et al., 2011; Soriani et al., 2012).

The postcalving RT of 340 to $540 \mathrm{~min} / \mathrm{d}$ observed here was within the range reported in the literature (Kononoff and Heinrichs, 2003b; Beauchemin and Yang, 2005; Yang and Beauchemin, 2006). Values above this range were reported by DeVries et al. (2009), with an average RT of $555 \mathrm{~min} / \mathrm{d}$ in mid-lactating cows, and in our previous work (Soriani et al., 2012), which found an average RT of $562 \mathrm{~min} / \mathrm{d}$ in early-lactating multiparous cows. The variability of RT reported in the literature is likely influenced by many factors, including MY, feed intake, diet composition, physiological status, health status, and heat stress. Among these, MY is one of the most important factors influencing RT, with several studies reporting greater MY associated with greater RT (DeVries et al., 2009; Soriani et al., 2012). We also found a positive correlation between MY and RT. However, both the MY level (on average $28.9 \mathrm{~kg} / \mathrm{d}$ in multiparous cows) and RT were lower in the present study than in previous studies. For instance, MY averaged 34.0 and $40.3 \mathrm{~kg} / \mathrm{d}$ in the experiments of DeVries et al. (2009) and Soriani et al. (2012), respectively.

Table 2. Plasma variables (LSM) before (Pre) and after (Post) calving in cows categorized according to rumination time observed between 3 and $6 \mathrm{DIM}^{1}$

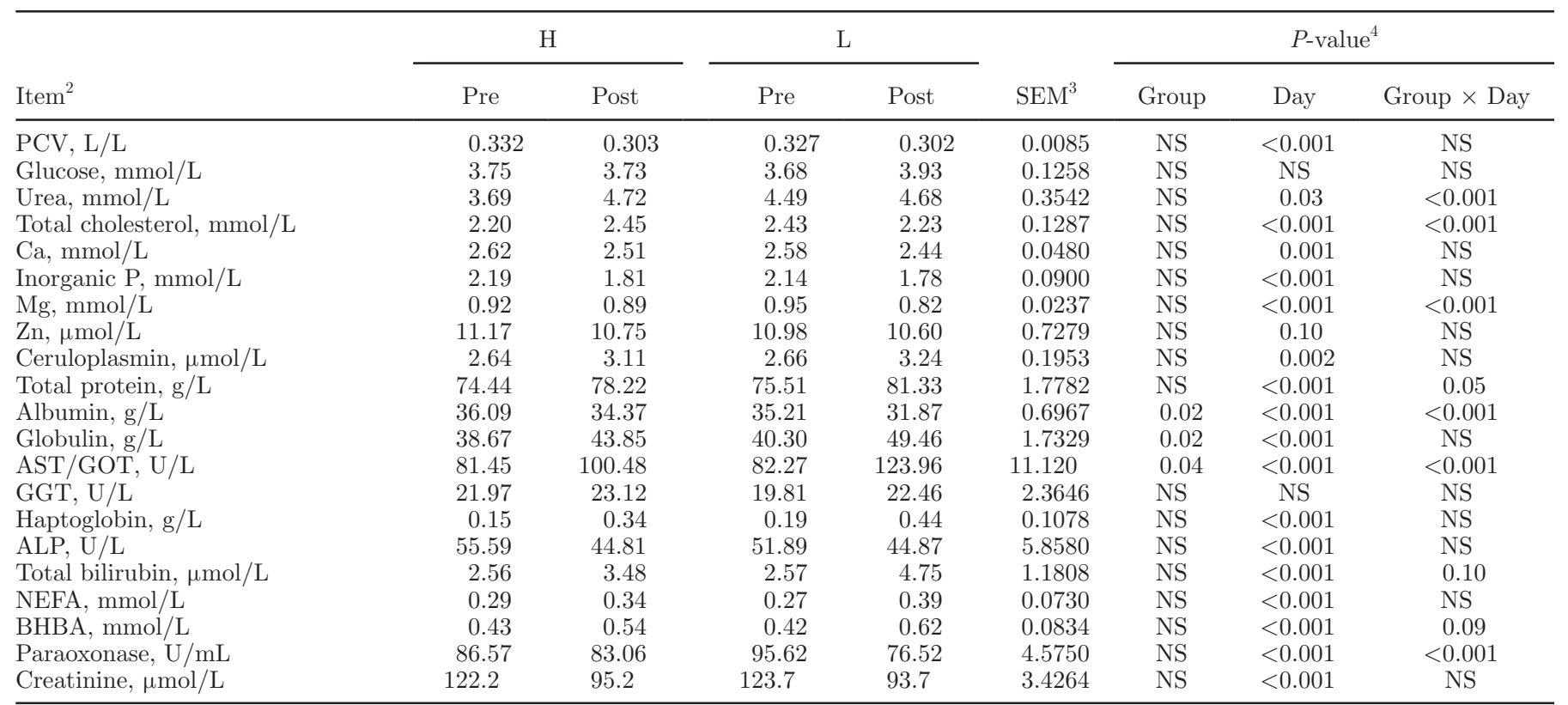

${ }^{1}$ Cows were categorized according to rumination time (RT) observed between 3 and 6 DIM (H = higher RT, 12 cows; L = lower RT, 11 cows). ${ }^{2} \mathrm{PCV}=$ packed cell volume; AST $/$ GOT $=$ aspartate aminotransferase; GGT $=\gamma$-glutamyltransferase; ALP $=$ alkaline phosphatase.

${ }^{3}$ Highest SEM.

${ }^{4}$ Group $=$ group effect; Day $=$ effect of days from calving. 
Table 3. Pearson correlation coefficients between rumination time and blood variables in the first month of lactation ${ }^{1}$

\begin{tabular}{lcccc}
\hline Item & 5 DIM & 10 DIM & 20 DIM & 30 DIM \\
\hline Total cholesterol & & $0.35^{*}$ & & \\
Albumin & & $0.34^{*}$ & $0.42^{* *}$ \\
Total bilirubin & $-0.57^{* * *}$ & $-0.64^{* * * *}$ & & \\
Paraoxonase & & $0.48^{* *}$ & & \\
Glucose & $-0.53^{* *}$ & & $-0.39^{*}$ & \\
NEFA & $-0.38^{*}$ & $-0.55^{* * *}$ & & \\
BHBA & $-0.35^{*}$ & $-0.65^{* * * *}$ & & \\
\hline
\end{tabular}

${ }^{1}$ The rumination time used in these correlations is the average value observed between 3 and 6 DIM.

${ }^{*} P<0.10 ;{ }^{* *} P<0.05 ;{ }^{* * *} P<0.01 ; * * * * P<0.001$.

Factors in the diet that affect RT have been studied in several experiments (Kononoff and Heinrichs, 2003b; Zebeli et al., 2006; Storm and Kristensen, 2010). In particular, Dado and Allen (1995) observed an increase of RT from 380 to $510 \mathrm{~min} / \mathrm{d}$ by increasing the NDF content of the diet from 25 to $35 \%$ of DM. Our RT in early lactation ( $452 \mathrm{~min} / \mathrm{d}$ ) was similar to the above and in agreement with values of 428 and $518 \mathrm{~min} / \mathrm{d}$ from recent work (Adin et al., 2009; Storm and Kristensen, 2010, respectively) with diets having NDF ranging from 31 to $35 \%$ (i.e., similar to our $34.6 \%$ NDF). Conversely, in our previous research (Soriani et al., 2012), we observed a greater RT $(562 \mathrm{~min} / \mathrm{d})$ compared with the value observed in the current study, in spite of a similar NDF content of the diet.

Our current and previous studies differed not only in the MY response but also in terms of particle size distribution of the TMR. In the current study, the TMR was characterized by a lesser amount of material retained on the 19.0- and 8.0-mm screens compared with that of Soriani et al. (2012), as well as a relatively high proportion of material on the pan. As observed by Kononoff and Heinrichs (2003a,b) and Kononoff et al. (2003), these characteristics can affect negatively RT and, thus, could partly explain the lower RT observed in this study.

Furthermore, in the current study, RT may have been adversely affected by climatic conditions. Indeed, the experimental barn used was located in the Po val-
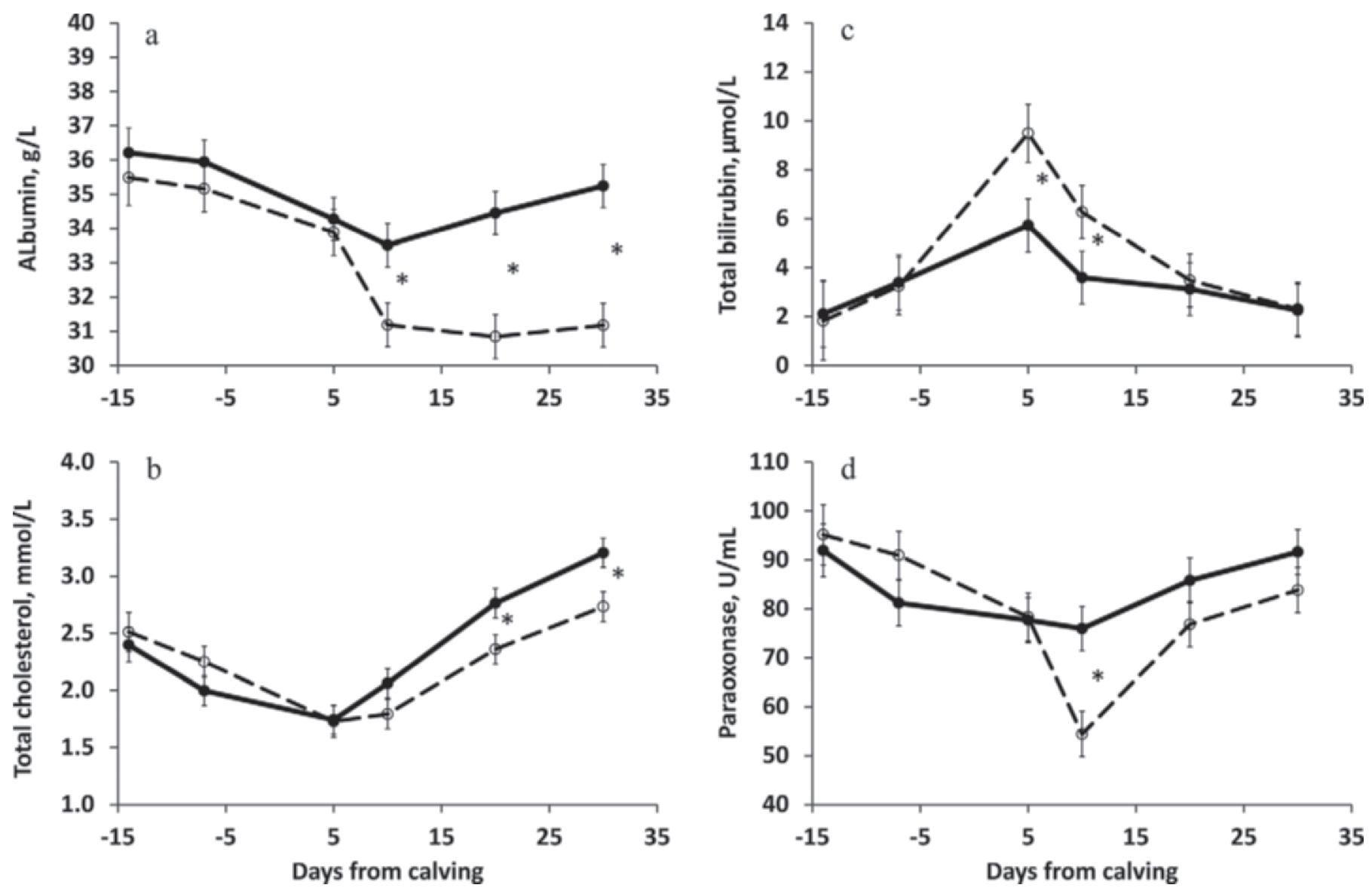

Figure 4. Pattern of plasma (a) albumin, (b) total cholesterol, (c) total bilirubin, and (d) paraoxonase during the transition period in cows categorized according to rumination time (RT) observed between 3 and 6 DIM (higher RT, $\bullet, n=12$; lower RT, O, n = 11). Values are LSM \pm SEM; asterisk $(*)$ indicates a difference between higher and lower RT cows, $P<0.05$. 

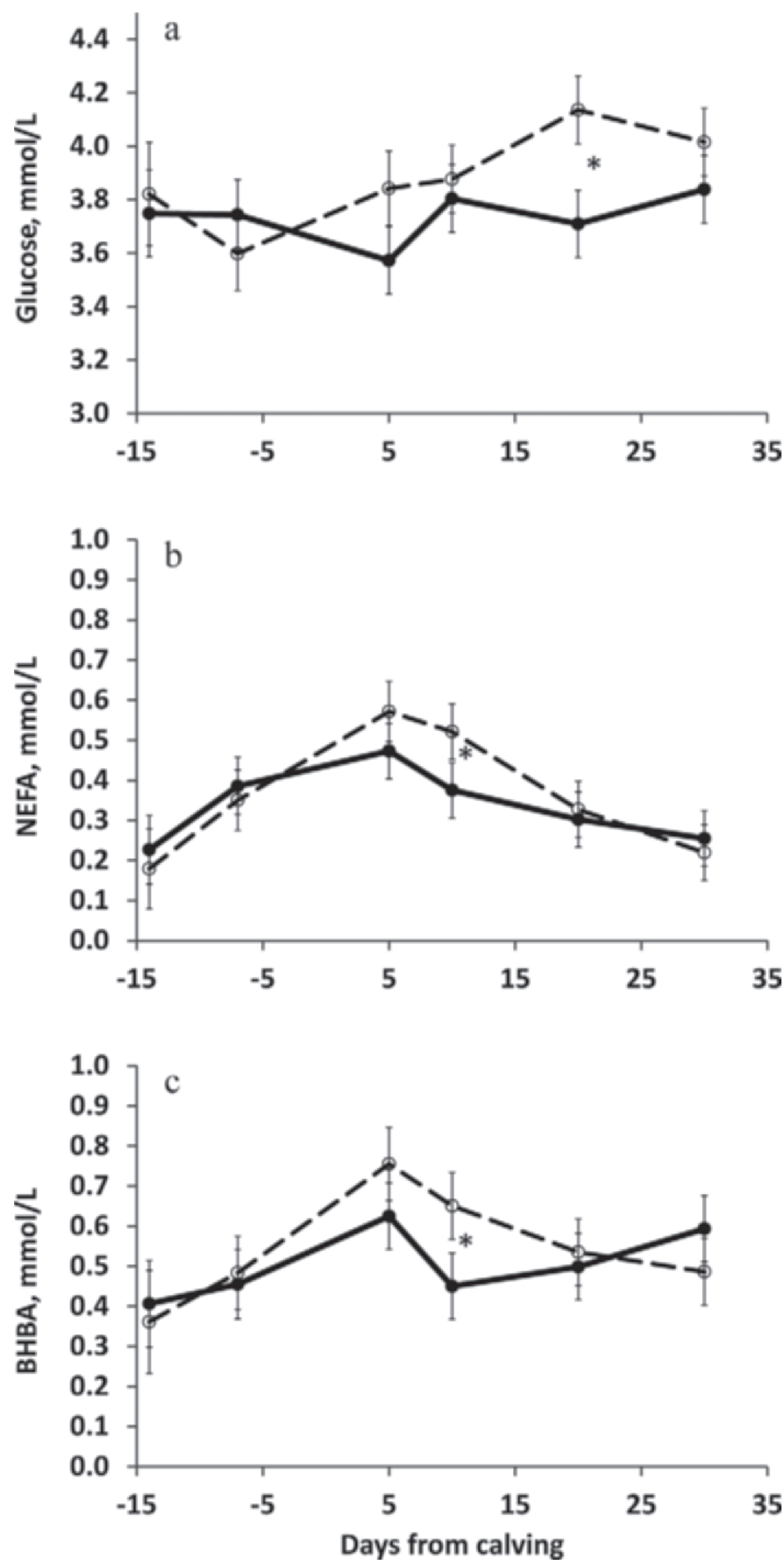

Figure 5. Pattern of plasma (a) glucose, (b) NEFA, and (c) BHBA during the transition period in cows categorized according to rumination time (RT) observed between 3 and 6 DIM (higher RT, $\bullet, n=12$; lower RT, $\mathrm{O}, \mathrm{n}=11$ ). Values are $\mathrm{LSM} \pm \mathrm{SEM}$; asterisk $(*)$ indicates a difference between higher and lower RT cows, $P<0.05$.

ley and cows calved from July to September; that is, during the hot season, in a region where microclimatic conditions are capable of inducing heat stress almost every day (Abeni et al., 2007; Calamari et al., 2011), as observed with the measurement of THI through this

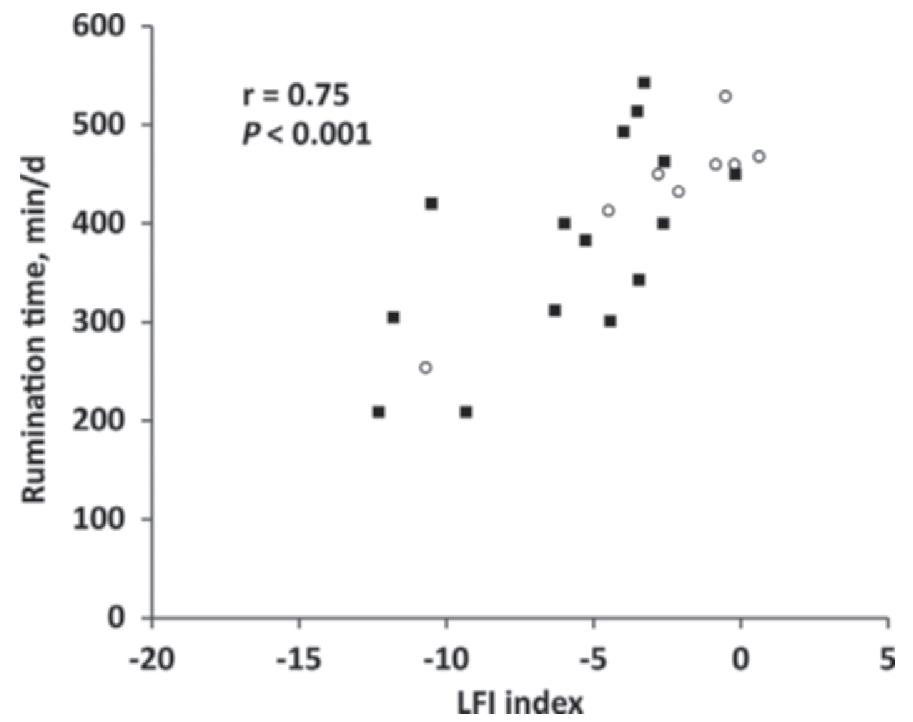

Figure 6. Rumination time (average value of data recorded between 3 and 6 DIM) and liver functionality index. Each symbol represents a cow; $\mathbf{\square}=$ cows affected by clinical diseases during the first 30 DIM, $\bigcirc=$ healthy cows. LFI = liver functionality index.

study. During heat stress, rumination is reduced in cows (Tapk and Sahin, 2006; Moallem et al., 2010), and the negative effect of hot conditions on RT is particularly evident on daytime RT, reducing the daytime:nighttime $\mathrm{RT}$ ratio (Soriani et al., 2013). Interestingly, the $\mathrm{L}$ cows (with lower RT between 3 and 6 DIM) were exposed around calving to similar microclimatic conditions of those of $\mathrm{H}$ cows for the short period in which they calved. Consequently, the negative effect of hot conditions on RT does not seem to explain the difference in $\mathrm{RT}$ between $\mathrm{L}$ and $\mathrm{H}$ cows.

The RT at calving was less than half that observed during the dry period, confirming the observations obtained in our previous study (Soriani et al., 2012). These results underscore the value of measuring RT before calving as a signal of impending calving. After calving, RT levels returned quickly to values observed in late pregnancy; on average, the maximum RT was reached between 5 and 15 DIM. Previous work reported similar results in cows without clinical diseases around calving; that is, RT had already reached a stable level at 5 DIM (Bar, 2011). Ideally, RT should be monitored continuously in the paddock, not a few times during the day (e.g., at the manger or watering place).

\section{Inflammation and Health Disorders}

Inflammatory status is one of the factors that reduce feed intake (Klasing, 2000; Trevisi et al., 2010) and RT. A model frequently used to induce inflammation is treatment with LPS. The LPS challenge may mimic 
low concentrations of circulating bacterial endotoxin during the beginning of an acute gram-negative infection. According to this model, reduction of RT in calves challenged with a low dose of LPS was observed by Borderas et al. (2008). Endotoxemia triggered metabolic and immunological alterations in dairy cows (Zebeli et al., 2011). In the current study, we assessed the consequence of inflammation occurring around calving in accordance with the LFI (Bertoni et al., 2006; Trevisi et al., 2012a). This index measures the variation of some negative acute-phase proteins or related parameters (albumin, cholesterol, and bilirubin; Trevisi et al., 2011) to help evaluate changes in liver function caused by inflammatory events. The synthesis of these negative acute-phase proteins is reduced during inflammation.

The low values of LFI observed in this study suggest not optimal metabolic conditions for animals in the herd compared with other experiments (Trevisi et al., 2010, 2012a; Soriani et al., 2012). A possible explanation could be the differences in season between studies, where microclimatic conditions in the current study were able to induce heat stress every day. The physiological response to heat load alters metabolism, impairs liver function, causes oxidative stress, depresses immune response, impairs reproductive performance, reduces MY, and impairs milk composition and its cheesemaking properties (Bernabucci and Calamari, 1998; Calamari and Mariani, 1998; Bernabucci et al., 2010). Besides other factors, it is known that heat stress can cause intestinal barrier disruption and endotoxemia, resulting in an inflammatory response (Lambert, 2009). Moreover, the higher concentration of plasma glucose in $\mathrm{L}$ cows compared with $\mathrm{H}$ cows in early lactation seems to suggest the presence of a state of insulin resistance in $\mathrm{L}$ cows. This is in agreement with the higher frequency of clinical diseases and the more severe inflammatory status observed in L cows, both conditions coherent with an insulin resistance state (Egger and Dixon, 2010; van Knegsel et al., 2014). Therefore, the very low average LFI in the current study was, at least in part, associated with the adverse climate conditions that could have worsened the inflammatory response around calving of all cows involved in this study. Because the cows calved in a very short period and always in hot conditions, the difference in LFI among cows seems only partly affected by the microclimatic conditions.

A strict relationship between LFI and health status and performance of dairy cows has been observed in previous work (Trevisi et al., 2010, 2012a). In particular, animals with low LFI had an increased frequency of clinical problems, greater loss of body reserves, lower feed intake in the first month of lactation, and lower MY. Those results suggest that a noticeable inflam- mation around parturition (e.g., low LFI) is associated with worsening of the health status (clinical or subclinical problems) and may cause a reduction of feed intake. These conditions are consistent with a reduction of RT as observed in this study. Moreover, the lower RT associated with the lower LFI confirmed results obtained by Borderas et al. (2008) and Soriani et al. (2012).

Indeed, cows with lower RT in early lactation were characterized by a larger increase of positive acutephase proteins after calving as well as lower LFI (e.g., lower levels and slower increase of negative acute-phase proteins after calving). Conversely, cows with higher LFI had greater RT in early lactation. These relationships underscore the close link between RT recorded during the first week of lactation and behavior of markers of inflammation, and they confirm the results of Bar (2011) and Soriani et al. (2012). Interestingly, after the first 10 DIM, this relationship was poor, suggesting the utility of RT for early detection of cows at a high risk of developing diseases during the days immediately after calving.

We observed a positive correlation between average RT after calving (from 3 to 6 DIM) and plasma paraoxonase recorded at 10 DIM. Plasma paraoxonase is a liver protein released into the blood stream and it is considered a negative acute-phase protein (Feingold et al., 1998; Trevisi et al., 2012b). If that is the case, a cause for decreased paraoxonase activity could be the existence of an inflammatory condition; that is, any serious disease. Indeed, paraoxonase had a negative correlation with positive acute-phase proteins and a positive correlation with negative acute-phase proteins (Bionaz et al., 2007) and LFI. Therefore, the marked reduction of paraoxonase after calving observed in this study, mainly in L cows, could be due to a lower rate of synthesis in the liver, when this organ is induced to help the immune system during the inflammatory response (Fleck, 1989; Bionaz et al., 2007).

It is well known that fever causes a reduction in RT (Fogsgaard et al., 2012). Rodenburg (2011) and Siivonen et al. (2011) observed a reduction in RT in cows with clinical mastitis. In particular, Siivonen et al. (2011) noted that cows showing the strongest clinical signs of mastitis spent more time eating but less time ruminating and drinking. A decrease in rumen contractions is a typical sign of clinical mastitis (Radostits et al., 2007). Almeida et al. (2008) indicated that lame cows also had significantly lower eating and ruminating behavior compared with healthy cows. Conversely, others (Walker et al., 2008) did not observe effects of lameness on the duration of drinking, grazing, or ruminating in cows after mo 2 of lactation. These apparently contrasting results can likely be explained by differences in the severity of lameness. 
Clinical health problems can occur often during the peripartum period. In the current study, only $1 \mathrm{cow}$ in the L group was sick just after calving, and 1 cow showed a clinical disease at 5 DIM. In these animals, the lower RT observed between 3 and 6 DIM could be a consequence of subclinical disease, which also often occurs peripartum (Bertoni et al., 2008). Nevertheless, most of the $\mathrm{L}$ cows that experienced health problems (lameness and ketosis) during the first month of lactation showed clinical manifestations after the first week of lactation. The slower increase in RT after calving in these cows compared with that observed in cows characterized by fewer health problems (H cows) agrees with the observations of Bar (2011) and Soriani et al. (2012), and this finding supports the use of RT monitoring after calving for the early detection of calving diseases. Pedersen (2010) studied RT in early-lactation cows affected by ketosis and found high individual variability in RT among the 114 cows evaluated; most of those animals were between 4 and $11 \mathrm{~d}$ postpartum. Pedersen (2010) concluded that RT could not identify cows at risk of ketosis in early lactation. A strong negative correlation between RT recorded between 3 and 6 DIM and plasma BHBA observed at 10 DIM was found in the current study, in contrast to the conclusion of Pedersen (2010). Interestingly, higher levels of plasma BHBA occurred in cows with lower LFI, suggesting that ketosis is often secondary to other health problems. Therefore, our results indicate that RT is a convenient tool to diagnose the primary cause of health problems.

\section{Rumination Time as Threshold of Acceptable Welfare}

Rumination time could be used as an index of the welfare of the herd, but it should be kept in mind that the average RT value varies in accordance with several factors. The cows with higher LFI (positive value) had an average RT around $500 \mathrm{~min} / \mathrm{d}$ between 3 and $6 \mathrm{~d}$ of lactation (Figure 6). In our previous work (Soriani et al., 2012), which used the liver activity index to measure the consequence of inflammation around calving, an $\mathrm{RT}>550 \mathrm{~min} / \mathrm{d}$ was observed between 2 and 10 DIM in cows with the best health status (e.g., higher liver activity index). The latter value of RT was proposed as a threshold for a good general condition of cows after calving.

The threshold observed in the present study was lower than the value proposed before (Soriani et al., 2012), as a consequence of the lower RT observed during the first month of lactation. The lower RT found in the current study might have been the result of climate conditions; the current study was conducted during the summer season, whereas the previous research was conducted during the winter (Soriani et al., 2012). The information obtained in our 2 studies indicates that the threshold of RT during the first $10 \mathrm{~d}$ of lactation is not an absolute value but that it is influenced by several factors that affect the average RT during the first month of lactation. This value can differ between herds and within herd throughout the season (Adin et al., 2009; Moallem et al., 2010; Calamari et al., 2011).

\section{CONCLUSIONS}

Calving diseases are very common and cause an increase in drug usage, veterinary cost, culling rate, and losses in production and reproduction. Farmers need quick and practical information to make rapid decisions to help reduce the incidence of calving disease. The automatic measurement of RT could help in this regard. Our results provide evidence that RT around calving is related to metabolic conditions (i.e., inflammatory indices and health status). Indeed, RT observed during the first $10 \mathrm{~d}$ of lactation is correlated with blood markers of inflammation and diseases observed during the first month of lactation. In particular, inflammation around parturition is associated with a slower increase in RT after calving. These relationships support the use of automatic measurements of RT as a tool in herd management. Further studies should focus on defining the thresholds of RT in different feeding systems and under different management and climatic conditions.

\section{ACKNOWLEDGMENTS}

This project was financially supported by the P.S.R. 2007-2013, Measure 124 (Cooperation to develop new products, processes and technologies in the agriculture, food, and forest sector; Regione Emilia Romagna, Bologna, Italy). The authors thank Milkline s.r.l. (Podenzano, Piacenza, Italy) for providing the Hi-Tag rumination monitoring system, as well as Massimiliano Intini (SCR Europe Srl, Podenzano, Piacenza, Italy) and Doron Bar (SCR Engineers Ltd., Netanya, Israel) for their technical support.

\section{REFERENCES}

Abeni, F., L. Calamari, and L. Stefanini. 2007. Metabolic conditions of lactating Friesian cows during the hot season in the Po valley. 1. Blood indicators of heat stress. Int. J. Biometeorol. 52:87-96.

Adin, G., R. Solomon, M. Nikbachat, A. Zenou, E. Yosef, A. Brosh, A. Shabtay, S. J. Mabjeesh, I. Halachmi, and J. Miron. 2009. Effect of feeding cows in early lactation with diets differing in roughageneutral detergent fiber content on intake or, rumination, and milk production. J. Dairy Sci. 92:3364-3373.

Almeida, P. E., P. S. D. Weber, J. L. Burton, and A. J. Zanella. 2008. Depressed DHEA and increased sickness response behaviours in 
lame cows with inflammatory foot lesions. Domest. Anim. Endocrinol. 34:89-99.

Bar, D. 2011. Daily rumination time and calving diseases. Accessed Dec. 21, 2011. http://www.kenes.com/buiatrics/cd/pdf/153.pdf.

Beauchemin, K. A. 1991. Ingestion and mastication of feed by dairy cattle. Vet. Clin. North Am. Food Anim. Pract. 7:439-463.

Beauchemin, K. A., and W. Z. Yang. 2005. Effects of physically effective fiber on intake, chewing activity, and ruminal acidosis for dairy cows fed diets based on corn silage. J. Dairy Sci. 88:2117-2129.

Bernabucci, U., and L. Calamari. 1998. Effects of heat stress on bovine milk yield and composition. Zoot. Nutr. Anim. 24:247-257.

Bernabucci, U., N. Lacetera, L. H. Baumgard, R. P. Rhoads, B. Ronchi, and A. Nardone. 2010. Metabolic and hormonal acclimation to heat stress in domesticated ruminants. Animal 4:1167-1183.

Bertoni, G., and E. Trevisi. 2013. Use of the liver activity index and other metabolic variables in the assessment of metabolic health in dairy herds. Vet. Clin. North Am. Food Anim. Pract. 29:413-431.

Bertoni, G., E. Trevisi, A. R. Ferrari, and A. Gubbiotti. 2006. The dairy cow performances can be affected by inflammations occurring around calving. Page 325 in Proc. 57th EAAP Mtg., Antalya, Turkey. EAAP, Rome, Italy.

Bertoni, G., E. Trevisi, X. Han, and M. Bionaz. 2008. Effects of inflammatory conditions on liver activity in the puerperium and consequences for performance in dairy cows. J. Dairy Sci. 91:33003310.

Bionaz, M., E. Trevisi, L. Calamari, F. Librandi, A. Ferrari, and G. Bertoni. 2007. Plasma paraoxonase, inflammatory conditions, liver functionality and health problems in transition dairy cows. J. Dairy Sci. 90:1740-1750.

Borderas, T. F., A. M. de Passillé, and J. Rushen., 2008. Behavior of dairy calves after a low dose of bacterial endotoxin. J. Anim. Sci. 86:2920-2927.

Calamari, L., N. Soriani, and M. Intini. 2011. Automatic measurement of rumination activity in lactating cows during summer season. Ital. J. Anim. Sci. 10(Suppl. 1):119F.

Calamari, L., and P. Mariani. 1998. Effects of the hot environment conditions on the main milk cheesemaking properties. Zoot. Nutr. Anim. 24:259-271.

Dado, R. G., and M. S. Allen. 1995. Intake limitations, feeding behavior, and rumen function of cows challenged with rumen fill from dietary fiber or inert bulk. J. Dairy Sci. 78:118-133.

DeVries, T. J., K. A. Beauchemin, F. Dohme, and K. S. SchwartzkopfGenswein. 2009. Repeated ruminal acidosis challenges in lactating dairy cows at high and low risk for developing acidosis: Feeding, ruminating, and lying behavior. J. Dairy Sci. 92:5067-5078.

Egger, G., and J. Dixon. 2010. Non-nutrient causes of low-grade, systemic inflammation: Support for a 'canary in the mineshaft' view of obesity in chronic disease. Obes. Rev. 12:339-345.

Feingold, K. R., R. A. Memon, A. H. Moser, and C. Grunfeld. 1998 Paraoxonase activity in the serum and hepatic mRNA levels decrease during the acute phase response. Atherosclerosis 139:307315.

Fleck, A. 1989. Clinical and nutritional aspects of changes in acute phase proteins during inflammation. Proc. Nutr. Soc. 48:347-354.

Fogsgaard, K. K., C. M. Røntved, P. Sørensen, and M. S. Herskin. 2012. Sickness behavior in dairy cows during Escherichia coli mastitis. J. Dairy Sci. 95:630-638.

Grant, R. J., and J. L. Albright. 2006 Feeding behaviour. Pages 365382 in Farm Animal Metabolism and Nutrition. J. P. F. D’Mello, ed. CABI International, Wallingford, UK.

Hansen, S. S., P. Norgaard, C. Pedersen, R. J. Jorgensen, L. S. B. Mellau, and J. D. Enemark. 2003. The effect of subclinical hypocalcaemia induced by $\mathrm{Na}_{2}$ EDTA on the feed intake and chewing activity of dairy cows. Vet. Res. Commun. 27:193-205.

Herskin, M. S., L. Munksgaard, and J. Ladewig. 2004. Effects of acute stressors on nociception, adrenocortical responses and behavior of dairy cows. Physiol. Behav. 83:411-420.

Ingraham, R. H., R. W. Stanley, and W. C. Wagner. 1979. Seasonal effects of tropical climate on shaded and non shaded cows as measured by rectal temperature, adrenal cortex hormones, thyroid hormone, and milk production. Am. J. Vet. Res. 40:1792-1797.
Kelly, C. F., and T. E. Bond. 1971. Bioclimatic Factors and Their Measurement: A Guide to Environmental Research on Animals. Natl. Acad. Sci., Washington, DC.

Klasing, K. C. 2000. Dietary approaches to protecting animal health. Pages 9-19 in Agenda 2000: The Food Revolution. European ed., Alltech, Nicholasville, KY.

Kononoff, P. J., and A. J. Heinrichs. 2003a. The effect of reducing alfalfa haylage particle size on cows in early lactation. J. Dairy Sci. 86:1445-1457.

Kononoff, P. J., and A. J. Heinrichs. 2003b. The effect of corn silage particle size and cottonseed hulls on cows in early lactation. J. Dairy Sci. 86:2438-2451.

Kononoff, P. J., A. J. Heinrichs, and D. A. Buckmaster. 2003. Modification of the Penn State forage and TMR separator and the effects of moisture content on its measurements. J. Dairy Sci $86: 1858-1863$.

Lambert, G. P. 2009. Stress-induced gastrointestinal barrier dysfunction and its inflammatory effects. J. Anim. Sci. 87(ESuppl.):E101-E108.

Lewis, G. S. 1997. Symposium: Health problems of the postpartum cow. Uterine health and disorders. J. Dairy Sci. 80:984-994.

Littell, R. C., P. R. Henry, and C. B. Ammerman. 1998. Statistical analysis of repeated measures data using SAS procedures. J. Anim. Sci. 76:1216-1231.

Moallem, U., G. Altmark, H. Lehrer, and A. Arieli. 2010. Performance of high-yielding dairy cows supplemented with fat or concentrate under hot and humid climates. J. Dairy Sci. 93:3192-3202.

NRC. 2001. Nutrient Requirements of Dairy Cattle. 7th rev. ed. Natl. Acad. Press, Washington, DC.

Pedersen, A. 2010. Rumination measurements and ketosis in early lactation. Dansk Veterinaertidsskrift. 93:28-32.

Radostits, O. M., C. C. Gay, K. W. Hinchcliff, and P. D. Constable. 2007. Mastitis. Pages $673-748$ in Veterinary Medicine. 10th ed. Saunders-Elsevier, Philadelphia, PA.

Rodenburg, J. 2011. Calving and cud chewing are highly correlated. Accessed Mar. 20, 2014. http://www.dairylogix.com/13-\%20Calving\% 20and\%20Cud\%20Chewing.pdf.

Schirmann, K., N. Chapinal, D. M. Weary, W. Heuwieser, and M. A. G. von Keyserlingk. 2011. Short-term effects of regrouping on behavior of prepartum dairy cows. J. Dairy Sci. 94:2312-2319.

Schirmann, K., M. A. G. von Keyserlingk, D. M. Weary, D. M. Veira, and W. Heuwieser. 2009. Technical note: Validation of a system for monitoring rumination in dairy cows. J. Dairy Sci. 92:6052-6055.

Siivonen, J., S. Taponen, M. Hovinen, M. Pastell, B. J. Lensink, S. Pyörälä, and L. Hänninen. 2011. Impact of acute clinical mastitis on cow behaviour. Appl. Anim. Behav. Sci. 132:101-106.

Soriani, N., G. Panella, and L. Calamari. 2013. Rumination time during the summer season and its relationships with metabolic conditions and milk production. J. Dairy Sci. 96:5082-5094.

Soriani, N, E. Trevisi, and L. Calamari. 2012. Relationships between rumination time, metabolic conditions and health status in dairy cows during the transition period. J. Anim. Sci. 90:4544-4554.

Storm, A. C., and N. B. Kristensen. 2010. Effects of particle size and dry matter content of a total mixed ration on intraruminal equilibration and net portal flux of volatile fatty acids in lactating dairy cows. J. Dairy Sci. 93:4223-4238.

Tapk, I., and A. Sahin. 2006. Comparison of the thermoregulatory behaviours of low and high producing dairy cows in a hot environment. Appl. Anim. Behav. Sci. 99:1-11.

Trevisi, E., M. Amadori, I. Archetti, N. Lacetera, and G. Bertoni 2011. Inflammatory response and acute phase proteins in the transition period of high-yielding dairy cows. Pages 355-380 in Acute Phase Proteins. 2nd ed. F. Veas, ed. InTech, Rijeka, Croatia.

Trevisi, E., M. Amadori, S. Cogrossi, E. Razzuoli, and G. Bertoni. 2012a. Metabolic stress and inflammatory response in high-yielding, periparturient dairy cows. Res. Vet. Sci. 93:695-704.

Trevisi, E., A. Ferrari, F. Piccioli-Cappelli, P. Grossi, and G. Bertoni. 2010. An additional study on the relationship between the inflammatory condition at calving time and net energy efficiency in dairy cows. Pages 489-490 in Energy and Protein Metabolism 
and Nutrition. EAAP Publication No. 127. Wageningen Academic Publishers, Wageningen, the Netherlands.

Trevisi, E., P. Grossi, T. Bacchetti, G. Ferretti, and G. Bertoni. 2012b. Variation factors of paraoxonase in blood and in HDL lipoproteins in dairy cow. Prog. Nutr. 14:43-49.

van Knegsel, A. T. M., H. M. Hammon, U. Bernabucci, G. Bertoni, R. M. Bruckmaier, R. M. A. Goselink, J. J. Gross, B. Kuhla, C. C. Metges, H. K. Parmentier, E. Trevisi, A. Tröscher, and A. M. van Vuuren. 2014. Metabolic adaptation during early lactation: Key to cow health, longevity and a sustainable dairy production chain. CAB Rev. 9:1-15.

Walker, S. L., R. F. Smith, J. E. Routly, D. N. Jones, M. J. Morris, and H. Dobson. 2008. Lameness, activity time-budgets, and estrus expression in dairy cattle. J. Dairy Sci. 91:4552-4559.

Welch, J. G. 1982. Rumination, particle size and passage from the rumen. J. Anim. Sci. 54:885-894.
Welch, J. G., and A. M. Smith. 1970. Forage quality and rumination time in cattle. J. Dairy Sci. 53:797-800.

Yang, W. Z., and K. A. Beauchemin. 2006. Effects of physically effective fiber on chewing activity and ruminal $\mathrm{pH}$ of dairy cows fed diets based on barley silage. J. Dairy Sci. 89:217-228.

Zebeli, Q., S. M. Dunn, and B. N. Ametaj. 2011. Intermittent parenteral administration of endotoxin triggers metabolic and immunological alterations typically associated with displaced abomasum and retained placenta in periparturient dairy cows. J. Dairy Sci. 94:4968-4983.

Zebeli, Q., M. Tafaj, H. Steingass, B. Metzler, and W. Drochner. 2006. Effects of physically effective fiber on digestive processes and milk fat content in early lactating dairy cows fed total mixed rations. J. Dairy Sci. 89:651-668. 